\title{
Metacognitive Skills of Malaysian Students in Non-Routine Mathematical Problem Solving
}

\author{
Habilidades Metacognitivas dos Estudantes Malaios na Resolução de \\ Problemas Não Rotineiros de Matemática
}

\author{
Abdul Halim Abdullah* \\ Sharifah Nurarfah S. Abd Rahman** \\ Mohd Hilmi Hamzah ${ }^{* * *}$
}

\begin{abstract}
Metacognitive skills play an important role in solving mathematical problems. However, there is a lack of empirical studies on the role of metacognitive skills in solving mathematical problems, particularly non-routine ones. Therefore, this study was undertaken to identify students' metacognitive skills and the impact of such skills on non-routine mathematical problem solving. By using a quantitative method, a total of 304 students in Johor Bahru district were involved in the study. A Self-Monitoring Questionnaire (SMQ) and a mathematical test were used in data collection. Data were analysed using descriptive and inferential statistics such as frequency, percentage, mean, the Mann-Whitney U test, and the Kruskal-Wallis H test. Results showed that the level of the students' performance in solving non-routine mathematical problems was very low. There was also a significant difference in the metacognitive skills among students with different performance levels in solving non-routine mathematical problems, and we concluded that these metacognitive skills should be emphasised in this process.
\end{abstract}

Keywords: Metacognitive Skills. Non-routine Problems. Mathematical Problem Solving.

\section{Resumo}

As competências metacognitivas desempenham um papel importante na resolução de problemas matemáticos. No entanto, existe falta de estudos empíricos sobre o papel das competências metacognitivas na resolução de problemas matemáticos, em particular os não rotineiros. Portanto, este estudo foi realizado para identificar competências metacognitivas dos alunos e o impacto de tais competências na resolução de problemas matemáticos não-rotineiros. Usando um método quantitativo, um total de 304 estudantes no distrito de Johor Bahru foram envolvidos no estudo. Questionário de Monitorização Autónomo (SMQ) e teste de matemática foram utilizados na recolha de dados. Os dados obtidos foram analisados por meio de estatística descritiva e inferencial, como a frequência, porcentagem, média, o teste de Mann-Whitney e Kruskal-Wallis H. Os resultados mostraram que o nível de desempenho dos alunos na resolução de problemas matemáticos não-rotineiros era muito baixa. Conclui-se uma diferença significativa nas competências metacognitivas entre estudantes com diferentes níveis de desempenho na resolução de problemas matemáticos não rotineiros. Concluiu-se que as competências metacognitivas devem ser enfatizadas no processo de resolução de problemas matemáticos não rotineiros.

\footnotetext{
* Faculty of Education, Universiti Teknologi Malaysia (UTM), 81310 Johor Bahru, MALAYSIA. E-mail: phalim@utm.my.

${ }^{* *}$ Faculty of Education, Universiti Teknologi Malaysia (UTM), 81310 Johor Bahru, MALAYSIA. E-mail: phalim@utm.my.

${ }^{* * *}{ }^{3}$ School of Education and Modern Languages, Universiti Utara Malaysia (UUM), Sintok, MALAYSIA. Email: p-halim@utm.my.
} 
Palavras-chave: Competências metacognitivas. problemas não rotineiros. Matemática. Resolução de Problemas.

\section{Introduction}

Problem solving in the context of education has received much attention these days. Its importance is recognised not only at the national level (Ministry of Education or MOE, 2006), but also at the international level (National Council of Teachers of Mathematics or NCTM, 2000). Problem solving is considered as the most important cognitive activity in daily life (Jonassen, 2000; Elia et al., 2009). Clements et al. (2002) also explain that problemsolving and reasoning form integral parts of the mathematical knowledge core. Thus, the problem solving process has always been the fundamental and primary area in research since the early 1980's (Bayat \& Tarmizi, 2010). Moreover, problem solving is a cognitive process that requires a solution for a given problem (Yingxu \& Chiew, 2010; Dusek \& Ayhan 2014). Therefore, students need to equip themselves with appropriate skills in the problem solving process, particularly in solving problems that require 'Higher Order Thinking Skills' (HOTS).

In the context of mathematics education, problems can be classified into routine and non-routine problems (MOE, 2006). According to Celebioglu et al. (2010), routine problems do not require students to use HOTS because such problems can be solved by replicating the methods experienced in the classroom. According to the NCTM (2000), mathematical problems refer to those presented to the students, yet the method to solve the problems is unknown beforehand. Normally, routine problems can be found in textbooks or workbooks. This scenario contradicts the Malaysian Education Blueprint (MEB) 2013-2025 that emphasises HOTS. Thus, to inculcate HOTS among the students, they need to be exposed to non-routine problems that have been classified by the NCTM (1989) as HOTS problems. Furthermore, Mabilangan et al. (2011) state that non-routine problem solving requires a higher cognitive level. According to the MOE, HOTS refers to the top four levels in the Revised Bloom's Taxonomy, which are to apply, analyse, evaluate, and create (Malaysia Examination Board or LPM, 2013). Instead of just memorising certain facts or concepts, the use of HOTS questions in the mathematical teaching and learning can train the students to master their learnt knowledge. (Stein et al., 2000). In short, non-routine problems require mastery in mathematical concepts and principles in advance, whereas routine problems are just daily routine that enable students to master basic mathematics. 
According to Schoenfeld (1985, 1987, 1992), Karmiloff-Smith (1992), Artzt \& Armour-Thomas (1992), and Lee et al. (2001), metacognition is a crucial aspect in problem solving. Verschaffel (1999) also recognises the importance of metacognition in problem solving. This is because metacognition involves cognitive processes (Hennessey, 2003) that may affect students' mathematical learning or behaviour. According to Zan (2000), mastering metacognitive skills will influence the performance in mathematics, particularly in mathematical problem solving. This is supported by Desoete et al. (2001) who show that metacognitive skills contribute to $37 \%$ in the performance level of mathematical problem solving. Rivers (2001) as well as Schraw and Dennison (1994) (in Imel, 2002) also claim that students with metacognitive skills are more strategic and brilliant than those without these skills.

Typically, previous studies have highlighted that metacognitive skills play a vital role in mathematical problem solving. Students' performance-whether they are successful or not - is potentially due to a lack of metacognitive skills, not cognitive skills (Chang, 2002). This problem is evident in the deterioration of Malaysian students' performance in international assessments, such as the Trends in International Mathematics and Science Study (TIMSS) and the Programme for International Student Assessment (PISA), in which the HOTS levels among the students were tested. Having recognised the importance of metacognition in mathematical problem solving, a review on the role of metacognition in nonroutine mathematical problem solving should thus be carried out. Furthermore, there is a lack of empirical studies that focus on the role of metacognitive skills in solving non-routine mathematical problems. Most studies in the past only considered mathematical problem solving with much less attention given to non-routine problems (Lee et al., 2012). Therefore, this study was undertaken to review students' metacognitive skills in solving non-routine mathematical problems. It focuses on metacognitive skills consisting of planning, monitoring, and evaluation processes (Spada, Georgiou \& Wells, 2010). In particular, this study aims to explore the students' performance level in solving non-routine mathematical questions and also to examine the difference in metacognitive skills among the students in solving nonroutine mathematical questions according to their performance level.

\section{Methodology}

A descriptive survey was carried out to achieve the objectives of the study. A total of 304 Form Four students in Johor Bahru district were involved. The selection of the sample in 
this study was based on a simple random sampling. There were two instruments used in this study. First, a set of questions was used to determine the students' performance level in solving non-routine mathematical questions. The questions consisted of four items dealing with non-routine mathematical problems. The performance score was determined based on the student initial score (raw score), standardised with Z and T scores (Mohd Najib, 2003). Z scores indicate the position of a score related to the distributed mean by using standard deviation (SD) as a measurement unit, while $\mathrm{T}$ scores standardise the score mean to 50 and the SD to 10 (Gravetter \& Wallnau, 2013). The performance level used in this study was based on the findings of the pilot study. Second, the Self-Monitoring Questionnaire (SMQ) was also employed in this study. It was adapted and modified based on the sample appropriateness via a combination of instruments from the studies by Fortunato et al. (1991), Schraw and Sperling-Denisson (1994), Panaoura et al. (2003), Biryukov (2002) and Zaidatun et al. (2008). This questionnaire consisted of 25 items that are categorised into three types of metacognitive skills, namely planning, monitoring, and evaluation in solving non-routine mathematical problems.

The data from the SMQ were analysed by using descriptive and inferential statistics. Mean, frequency, and percentage used to discuss the findings were obtained by using Statistical Package for Social Sciences (SPSS version 20.0). The determination of an average score (mean) for the Section B of the questionnaire is shown in Table 1. Next, Mann-Whitney $\mathrm{U}$ and Kruskal-Wallis tests were conducted to explore the differences in the performance of the Form Four students in solving non-routine mathematical problems across the performance levels based on the distributed set of questions.

Table 1 - Description of the mean values

\begin{tabular}{cc}
\hline Mean value & Description \\
\hline $1.00-2.33$ & Low \\
$2.34-3.67$ & Medium \\
$3.68-5.00$ & High \\
\hline \multicolumn{2}{c}{ Source: Landell (1977) }
\end{tabular}

\section{Results}

Table 2 shows the distribution of the students' score and their performance level in solving non-routine mathematical problems. Results showed that $38.8 \%$ (118) of the respondents had a very low performance level, followed by $22.7 \%$ (69) of the respondents with a low performance level. Only $8.2 \%$ (25) and $19.1 \%$ (58) of respondents showed high and very high performance levels, respectively. This shows that the majority of the 
respondents in this study had a low performance level in solving non-routine mathematical problems.

Table 2 - Distribution of student scores according to the test set by performance level

\begin{tabular}{llcc}
\hline Scores & Performance Level & Frequency & $\begin{array}{c}\text { Percentage } \\
(\%)\end{array}$ \\
\hline 0.00 to 33.88 & Very Low & 118 & 38.8 \\
33.89 to 43.87 & Low & 69 & 22.7 \\
43.88 to 53.88 & Medium & 34 & 11.2 \\
53.89 to 63.87 & High & 25 & 8.2 \\
63.88 and above & Very High & 58 & 19.1 \\
\hline Total & & $\mathbf{3 0 4}$ & $\mathbf{1 0 0}$ \\
\hline
\end{tabular}

Source: Mohamad Najib (2003), Lee (2013)

Next, the students' raw score was obtained from their written work in solving four items of non-routine mathematical problems that tested their HOTS level. Among the items of non-routine mathematical problems presented in this study, two are shown in the table below:

Table 3 Two Items of non-routine problems

\begin{tabular}{|c|c|}
\hline Item & Question \\
\hline 1 & $\begin{array}{l}\text { Mr. Hamid had a tank full of water in his backyard to be used when the water was running out. } \\
\text { The tank was cylindrical with a radius of } \sqrt{ } 120 \mathrm{~cm} \text { and a height of } 2 h \text {. Then, in the absence of } \\
\text { water, Mr. Hamid flowed the water out of the tank through pipe A and pipe B at a rate of } \\
18 \pi \mathrm{l} / \mathrm{min} \text { and } 20 \pi \mathrm{l} / \mathrm{min} \text {, respectively. } \\
\text { If pipe B was opened one minute after pipe A, how long did it take to empty the tank? Explain } \\
\text { your answer. }\end{array}$ \\
\hline 2 & $\begin{array}{l}\text { A person was found to have spilt water. } \\
\text { Four people were there at that time: Amanda, Suziana, Iman, and Rafiq. They were questioned } \\
\text { by one of the mothers. } \\
\text { Amanda: "It wasn't me who spilled the water" } \\
\text { Rafiq: "Iman spilled the water!" } \\
\text { Suziana: "It was Rafiq" } \\
\text { Iman: "Rafiq was lying" } \\
\text { If only one person was telling the truth, who actually spilt the water? Explain your answer. }\end{array}$ \\
\hline
\end{tabular}
Source: Research data

The students' raw scores were categorised as shown in Table 2. The researchers also identified some aspects in the students' solving steps, particularly the use of metacognitive skill elements in solving the non-routine mathematical problems items. The criteria of the results from the students' written answers according to their performance level are shown in Table 4 below:

Table 4 Result of Student solving criteria

\begin{tabular}{|c|c|}
\hline Level & Solution criteria for students' answer \\
\hline Very High & $\begin{array}{l}\text { - } \begin{array}{l}\text { Students outline and extract the key information from the questions into comprehensible } \\
\text { - } \\
\text { - }\end{array} \text { Students are able to scan existing knowledge properly (e.g., writing the formula) } \\
\text { - } \quad \text { The steps shown in the solution are organised, clear, and understandable. } \\
\text { of eraser, change of strategy) } \\
\text { - The final answer given is accurate with justification. } \\
\text { - Students are able to provide explanations for certain items in a proper and logical manner } \\
\text { (if any). }\end{array}$ \\
\hline
\end{tabular}




\begin{tabular}{|l|ll|}
\hline High & - & Students outline the answer and rewrite the key information in a comprehensible manner. \\
& - & The existing knowledge is displayed in the steps for the solution. \\
& - & There are calculation errors in the solution steps, but the methods used are correct. \\
- & The final answer given is accurate but lacks logical explanation.
\end{tabular}

Source: Research data

Based on the solution criteria, there are some metacognitive skills shown in the solution steps, such as outlining key information within an item, translating information into an understandable form, considering alternative solutions, and revising the steps for solution. However, the findings showed that most of the students are at a very low level with scores ranging between 0.00 and 33.88. This shows us that the students are very weak in solving the non-routine items and they displayed a lack of metacognitive skills. On the other hand, the students who exhibited a very high performance level displayed excellent solution criteria and high metacognitive skills. However, the students with high marks ranging between 63.88 and above constituted only $19.1 \%$ (58) of the respondents. This amount is less than half of the number of students with a very low performance, i.e., 38.8\% (118).

The Kruskal-Wallis $\mathrm{H}$ analysis was performed to identify whether there was a significant difference of metacognitive skills among the students with different performance levels in non-routine problem solving. The dependent variable used was the meta-cognitive skill level, and the independent variable was the performance level from the test set. The ordinal scale data were used as a dependent variable. This coincides with the condition set by Chua (2008) in which the Kruskal-Wallis H test is used when the dependent variable is in ordinal scale, and the independent variables can be classified into more than two categories. The overall result from the Kruskal-Wallis $\mathrm{H}$ test showed that there was a significant difference among the five groups of students $\left[X^{2}(4, \mathrm{~N}=304)=217.649, \mathrm{p}=.000<.05\right]$. Table 5 depicts the Kruskal-Wallis $\mathrm{H}$ test analysis. 
Table 5: Level of metacognitive skills according to performance level

\begin{tabular}{llllll}
\hline & & Mean Rank & $H$ & $\begin{array}{c}\text { d } \\
\text { f }\end{array}$ & Sig. \\
\hline & Very high & 263.28 & 217.649 & 4 & .000 \\
Metacognitive Skill & High & 260.38 & & & \\
& Medium & 197.12 & & & \\
& Low & 100.70 & & \\
& Very Low & 92.63 & & \\
\hline \multicolumn{5}{c}{ Source: Research data }
\end{tabular}

Next, the Mann-Whitney U test was performed to identify the respondent group pair that contributed to the significant difference. Table 6 shows a comparison between the pairs in the five respondent groups.

Table 6: Comparison between metacognitive skills for performance level group pair

\begin{tabular}{|c|c|c|c|c|c|}
\hline & & $\begin{array}{l}\text { Mean Rank } \\
\text { Difference }\end{array}$ & $\boldsymbol{U}$ & $\mathbf{Z}$ & Sig. \\
\hline Metacognitive & $1-2$ & 2.49 & 681.500 & -.435 & .663 \\
\hline \multirow[t]{9}{*}{ Skills } & $1-3$ & 44.74 & 27.000 & -7.775 & .000 \\
\hline & $1-4$ & 63.50 & .000 & -9.696 & .000 \\
\hline & $1-5$ & 88.00 & .000 & -10.785 & .000 \\
\hline & $2-3$ & 27.97 & 22.000 & -6.190 & .000 \\
\hline & $2-4$ & 47.00 & .000 & -7.390 & .000 \\
\hline & $2-5$ & 71.5 & .000 & -7.855 & .000 \\
\hline & $3-4$ & 46.23 & 120.000 & -7.392 & .000 \\
\hline & $3-5$ & 69.18 & 180.000 & -8.087 & .000 \\
\hline & $4-5$ & 7.86 & 3729.000 & -.960 & .337 \\
\hline
\end{tabular}

*1=Very High; 2=High, 3=Medium, 4=Low, 5=Very Low

Source: Research data

Results from the Mann-Whitney $U$ test analysis show that there is a significant difference $(\mathrm{p}<.005)$ between the groups classified as follows: very high and medium, very high and low, very high and very low, high and medium, high and low, high and very low, medium and low as well as medium and very low. However, there is no significant difference ( $\mathrm{p}>.005)$ between the groups classified as very high and high $(\mathrm{Z}=-.435, \mathrm{p}=.663)$ as well as groups classified as low and very low $(\mathrm{Z}=-.960, \mathrm{p}=.337)$.

\section{Discussion}

Based on the analysis for determining the students' performance level in non-routine problem solving, we found that the students' performance level is still very low, with marks ranging between 0.00 and 33.88. In addition, teachers rarely emphasised on non-routine problem solving in classrooms (Silver et al., 2005; Leikin \& Levav-Waynberg, 2007). These findings echo those in Abdul Halim Abdullah et al. (2014) in Malaysia, in which the teachers' skill in solving non-routine mathematical problems was found to be weak despite having a 
good knowledge about non-routine problem solving. This is due to the lack of HOTS elements applied to the students in the classroom.

In addition, this study also considered metacognitive skills in solving non-routine mathematical problems with HOTS elements. The findings demonstrated that the students' metacognitive skills in the non-routine mathematical problem solving were at a medium level. These findings are consistent with those found by Saemah Rahman (2004), who reported that there are still shortcomings in terms of metacognitive practice among weaker students. Some of the weaknesses identified are lack of planning, implementation, and revision skills during the students' learning. In addition, the study found that the students' monitoring skill was at its highest level as compared to the planning and evaluation skills. The study done by Zaidatun et al. (2008) also proves that students are more likely to use monitoring skill as compared to other metacognitive skills. This shows that, even though most students could not fully comprehend the question, they executed ambiguous solution strategies, thus causing them to be unable to write a correct and accurate answer.

Other findings showed that there was a difference in metacognitive skills among the students with very high, high, medium, low, and very low performance levels. This observation was based on the students' performance in answering the non-routine questions presented in this study. It was found that the students with a very high performance level were directly proportional to the metacognitive skills. This means that metacognitive skills did affect their performance. In line with the study conducted by Zan (2000), metacognitive intelligence would affect the performance in Mathematics, especially in the mathematical problem solving. This finding also accords well with the study of Desoete et al. (2001) that shows that metacognitive skills contribute $37 \%$ to the performance in the mathematical problem solving. The study done by Nuraisyah Mohamad and Zamri Mahamod (2014) also showed that metacognitive skill awareness can boost interest, thus improving the performance in a particular subject. In addition, several studies showed that, through metacognitive exercises, the student's ability in solving mathematical problems can be improved (Jacobs \& Harskamp, 2012). Furthermore, the findings from Bayat \& Tarmizi (2010) study showed that there is a positive and moderate significant relationship between a metacognitive overall strategy and the performance in the Algebra problem solving.

However, the metacognitive skills in the written work differ between very low and very high performance students. Low-level students are considered to have limitations in solving non-routine mathematical problems. According to Donner and Wearing (1995) and Funke (1991), among the difficulties encountered in solving the difficult problems are the 
lack of clarity on the problem situation, the high level of question difficulty and time constraint due to the lengthy and difficulty of questions. This is because non-routine problems do not have simple solutions at a first glance. Instead, they require a different reasoning and the use of certain heuristic strategies (Celebioglu et al., 2010).

\section{Conclusion}

The current education system is concerned with the students' HOTS level in order to fulfill the MEB 2013-2025 agenda, which is to produce individuals who have a creative and critical thinking. The students' HOTS level can be enhanced via non-routine problem solving. However, the study found that the students' performance in non-routine mathematical problem solving was unsatisfactory and their metacognitive skill was at a medium level. Therefore, teachers should expose students to other forms of non-routine problem solving besides reducing the usage of questions available in the textbook. Meanwhile, students need to prepare themselves with high metacognitive skills. These skills assist students in understanding, planning, implementing a strategy, rectifying errors, and evaluating answers to the mathematical problem solving. Therefore, students with high level of metacognitive skills can improve their performance, thus acquiring the much-needed requirement of HOTS.

\section{Acknowledgments}

The authors would like to thank Universiti Teknologi Malaysia its financial support. This work was supported by the GUP Tier 1 Grant no. Q.J130000.2531.13H32.

\section{References}

ABDULLAH, A. H. et al. Non-routine mathematical problems among in-service and pre-service mathematics teachers. In: INTERNATIONAL CONFERENCE OF TEACHING, ASSESSMENT AND LEARNING (TALE), 2014, Wellington New Zealand. Proceedings of IEEE International Conference on Teaching, Assessment and Learning for Engineering: Learning for The Future Now. USA: IEEE, 2014. p. 18-24.

ARTZT, A. F.; ARMOUR-THOMAS, E. Development of a cognitive-metacognitive framework for protocol analysis of mathematical problem solving in small groups. International Journal of Cognition and Instruction, Lawrence, Kansas, v. 9, n. 2, p. 137-175, 1992.

BAYAT, S.; TARMIZI, R. A. Assessing cognitive and metacognitive strategies during algebra problem solving among university students. Procedia - Social and Behavioral Sciences, United Kingdom, v. 8, p. 403-410, 2010. 
BIRYUKOV, P. Metacognitive aspects of solving combinatorics problem. International Journal in Education Mathematics, Berlin, Germany, v. 74, p. 1-9 mac. 2002.

CELEBIOGLU, B.; YAZGAN, Y.; EZENTAS, R. Usage of non-routine problem solving strategies at first grade level. Procedia - Social and Behavioral Sciences, United Kingdom, v. 2, p. 2968-2974, 2010.

CHANG S. C. A. Teacher's Handbook on Learning Generic Thinking Skills. enter edition number. ed. Singapore: Prentice Hall, 2002. 133 p.

CHUA, Y. P. Asas Statistik Penyelidikan. 2. ed. Shah Alam: McGraw-Hill Education, 2008. 373 p.

CIASCAI, L.; LAVINIA, H. Gender differences in metacognitive skills. A study of the 8th grade pupils in romania. Procedia - Social and Behavioral Sciences, United Kingdom, v. 29, p. 396-401, 2011.

CLEMENTS, D.; COPPLE, C.; HYSON, M. Early childhood mathematics: promoting good beginnings. National Association for the Education of Young Children (NAEYC) and the National Council of Teachers of Mathematics (NCTM), Washington, D.C, v. 17, p. 1-21, 2002.

DESOETE, A.; ROEYERS, H.; BUYSSE, A. Metacognition and mathematical problem solving In grade 3. Journal of Learning Disabilities, Belgium, v. 34, p. 435-449, 2001.

DORNER, D.; WEARING, A. Complex problem solving: toward a (computer-simulated) theory. In: FRENSCH, P. A.; FUNKE, J. (Ed.). Complex Problem Solving: the European Perspective. Hillsdale: Ed. Lawrence Erlbaum Associates, 1995. p. 65-99.

DUSEK, G.; AYHAN, A. B. A study on problem solving skills of the children from broken family and full parents family attending regional primary boarding school. Procedia-Social and Behavioral Sciences, United Kingdom, v. 152, p. 137-142, 2014.

ELIA, I.; VAN DEN HEUVEL-PANHUIZEN, M.; KOLOVOU. A. Exploring strategy use and strategy flexibility in non-routine problem solving by primary school high achievers in mathematics. International Journal on Mathematics Education, ZDM, Germany, v. 41, p. 605-618, 2009.

FORTUNATO, I. et al. Metacognition and problem solving. Arithmetic Teacher, Reston, v. 39, n. 4, p. 38-40, 1991.

GARDNER, H. The Unschooled Mind: how children think and how schools should teach. 2. ed. New York: Basic, 1991. 303 p.

GHAFAR, M. N. A. Reka Bentuk Tinjauan Soal Selidik. 1. ed. Skudai: Fakulti Pendidikan Universiti Teknologi Malaysia, 2003. 268 p.

GRAVETTER, F. J.; WALLNAU, L. B. Statistics For The Behavioural Sciences. 9. ed. Belmont, CA: Wadsworth, 2013. 767 p.

HENNESSEY, M. G. metacognitive aspects of students' reflective discourse: implications for intentional conceptual teaching and learning. In: SINATRA, G. M.; PINTRICH, P. R. (Ed.). Intentional Conceptual Change. Mahwah: Ed. Lawrence Erlbaum, 2003. p. 103-132.

IMEL, S. Metacognitive Skills for Adult Learning. ERIC Clearing house on Adult, Career, and Vocational Education, Center on Education and Training for Employment, College of Education, the Ohio State University, 2002. 
MARCHIS, I. Non-routine problems in primary mathematics workbooks from Romania. Acta Didactica Napocensia, Romania, v. 5, n. 3, p. 49-56, 2012.

JACOBSE, A. E.; HARSKAMP, E. G. Towards Efficient Measurement of Metacognition in Mathematical Problem Solving. Metacognition and Learning, v.7, p. 133-149, 2012.

JONASSEN, D. H. Toward a design theory of problem solving. Educational Technology Research and Development, USA, v. 48, n. 4, p. 63-85, 2000.

KARMILOFF-SMITH, A. Beyond Modularity: a developmental perspective on cognitive science. 1. ed. Cambridge: MIT Press, 1995. 239 p.

KAZEMI, F.; FADAEE, M. R.; BAYAT, S. A subtle view to metacognitive aspect of Mmathematical problems solving. Procedia - Social and Behavioral Sciences, United Kingdom, v. 8, p. 420-426, 2010.

LANDELL, K. Management By Menu. 1. ed. London: Wiley and Sons Inc, 1997. 432 p.

LAPORAN PELAN PEMBANGUNAN PENDIDIKAN MALAYSIA (PPPM) 2013-2025.

Kementerian Pendidikan Malaysia, 2012.

LEE, J. H. Aplikasi Konsep Fizik dalam Menyelesaikan Masalah yang Berasaskan STEM bagi Pelajar Tingkatan Enam Atas. 276 f. Tesis (Sarjana) - Fakulti Pendidikan, Universiti Teknologi Malaysia, Skudai, 2013.

LEE N. H.; CHANG A. S. C.; LEE P.Y. The role of metacognition in the learning of mathematics among low- achieving students. Teaching and Learning, Singapore, v. 22, n. 2, p. 18-30, 2001.

LEE, C. et al. Children's use of meta-cognition in solving everyday problems: children's monetary decision. Australian Journal of Education, Australia, v. 56, n. 1, p. 22-39, 2012.

LEIKIN, R.; LEVAV-WAYNBERG, A. Exploring mathematics teacher knowledge to explain the gap between theory-based recommendations and school practice in the use of connecting tasks.

Educational Studies in Mathematics, Netherlands, v. 66, n. 3, p. 349-371, 2007.

LEMBAGA PEPERIKSAAN MALAYSIA (LPM). Pentaksiran Kemahiran Berfikir Aras Tinggi. Kementerian Pendidikan Malaysia, 2013.

MABILANGAN, R. A.; LIMJAP, A. A.; BELECINA, R. R. Problem solving strategies of high school students on non-routine problems: a case study. Alipato: A Journal of Basic Education, Hong Kong, v. 5, p. 23-46, 2011.

MINISTRY OF EDUCATION MALAYSIA. Integrated curriculum for secondary schools: curriculum specifications mathematics form 4. Kuala Lumpur: Curriculum Development Centre, Ministry of Education Malaysia, 2006.

MOHAMAD, N. A.; MAHAMOD, Z. Tahap kemahiran metakognitif murid tingkatan empat dalam pembelajaran bahasa melayu. Jurnal Pendidikan Bahasa Melayu. Malay Language Education, v. 4, n. 1, p. 41-47, 2014.

MOHAMAD NAJIB A. G. Rekabentuk Tinjauan Soal Selidik Pendidikan. 1. ed. Skudai : Penerbit Universiti Teknologi Malaysia, 2003. 268 p.

NATIONAL COUNCIL OF TEACHERS MATHEMATICS. Principle and Standards For School Mathematics. 3. ed. Reston: NCTM, 2000. 402 p. 


\section{NATIONAL COUNCIL OF TEACHERS OF MATHEMATICS. Curriculum and Evaluation} Standards for School Mathematics. 1. ed. Reston: VA, 1989. 258 p.

O’NEIL, H. F. JR.; ABEDI, J. Reliability and Validity of State Metacognitive Inventory: Potential for Alternative Assessment. Journal of Educational Research, Washington, D.C., v. 89, n. 4, p. 234245, 1996.

PANAOURA, A; PHILIPPOU, G. I.; CHRISTOU, C. The Construct Validity of an Inventory for the Measurement of Young Pupils' Metacognitive Abilities in Mathematics. European Research in Mathematics Education Ill: group3, Cyprus, v. 3, n. 2003, p. 437-444, 2003.

RAHMAN, S.. Hubungan Antara Metakognisi, Motivasi dan Pencapaian Akademik Pelajar Universiti. 275 f. Tesis (Doktor Falsafah) - Fakulti Pendidikan, Universiti Malaya, Kuala Lumpur, 2004.

SCHNEIDER, W.; ARTELT, C. Metacognition and mathematics education. International Journal on Mathematics Education, ZDM, Germany, v. 42, n. 2, p. 149-161, 2010.

SCHOENFELD, A. H. Mathematical Problem Solving. 1. ed. Hillsdale: Lawrence Erlbaum Associates, 1985. $409 \mathrm{p}$.

SCHOENFELD, A. H. What's All The Fuss About Metacognition? In: (Ed.). Cognitive Science and Mathematics Education. Hillsdale: Ed. Lawrence Erlbaum Associates, 1987. p. 189215.

SCHOENFELD, A. H. Learning to think mathematically: problem-solving, metacognition, and sensemaking in mathematics. In: GROUWS, D. A. (Ed.). Handbook on Research on Mathematics Teaching \& Learning. New York: Ed. Macmillan Publishing Group, 1992. p. 334-370.

SCHRAW, G.; DENNISON, R. S. Assessing metacognitive awareness. Contemporary Educational Psychology, United States, v.19, n. 4, p. 460-475, 1994.

SILVER, E. A. et al. Moving from rhetoric to praxis: issues faced by teachers in having students consider multiple solutions for problems in the mathematics classroom. The Journal of Mathematical Behavior, Oxford, v. 24, n. 3, p. 287-301, 2005.

SPADA, M.; GEORGIOU, G.; WELLS, A. The relationship between metacognitions, attentional control and state anxiety. Cognitive Behaviour Therapy, Abingdon, United Kingdom, v. 39, n. 1, p. 64-71, 2010.

STEIN, M. K. et al. Implementing Standards - Based Mathematics Instruction: a casebook for professional development. 1. ed. New York: Teachers College Press, 2000. 146 p.

TASIR, Z.; HARUN, J.; ZAKARIA, N. W. Tahap kemahiran metakognitif pelajar dalam menyelesaikan masalah matematik. In: SEMINAR KEBANGSAAN PENDIDIKAN SAINS DAN MATEMATIK, 2008, Skudai. Minutes of... Skudai: Universiti Teknologi Malaysia, 2008. p. 1-11.

VERSCHAFFEL, L. Realistic mathematical modelling and problem solving in the upper elementary school: analysis and improvement. In: HAMERS, J. H. M.; VAN LUIT, J. E. H.; CSAPO, B. (Ed.). Teaching and Learning Thinking Skills: contexts of learning. Lisse: Ed. Swets \& Zeitlinger, 1999. p. 215-240.

YINGXU, W. Y.; CHIEW, V. On the cognitive process of human problem solving. Cognitive Systems Research, Amsterdam, Netherlands, v. 11, n. 1, p. 81-92, 2010. 
ZAN, R. A metacognition interaction in mathematics at university level. International Journal of Mathematical Education in Science and Technology, New Jersey, United States, v. 37, n. 1, p. 143$150,2000$.

Submetido em Abril de 2016. Aprovado em Outubro de 2016. 